\title{
BUSINESS
}

\section{A place in the sun}

\section{In the Tuscan countryside just outside Siena, a historic laboratory is helping Novartis in its bid to become the world's premier vaccine company. Alison Abbott reports.}

$\mathrm{N}$ o one attending one of Rino Rappuoli's symposia in Siena, Italy, could fail to be seduced by his laboratory's melding of modern efficiency and old-world charm. The Sclavo Institute may have top-of-the-range facilities, but there is still scope for lunch on the terrace accompanied by a glass of chianti and uninterrupted views of the Tuscan hills.

What might surprise some outside visitors enjoying the lab's exceptional ambience is its newfound role as the intellectual engine behind the multibillion-dollar vaccine arm of Swiss drug company Novartis.

"The research group at Siena has a long history of being at the cutting edge," says Stanley Falkow, a molecular microbiologist at Stanford University in California. So when Novartis took control of the lab, as part of its acquisition of California biotech firm Chiron last April, it inherited a broad portfolio of vaccine candidates, he says.

On 28 November, Novartis, satisfied with the fruits of its acquisition to date, declared its intention to become the world leader in vaccines. Last year, it was the fifth-largest supplier in a US\$11-billion market, with $\$ 965$ million in vaccine sales.

The tradition of vaccine research on the Siena site goes back a long way. In 1904, Achille Sclavo, who developed the first protective serum against anthrax, founded a vaccine and serology institute at his home outside the old city walls. Sales

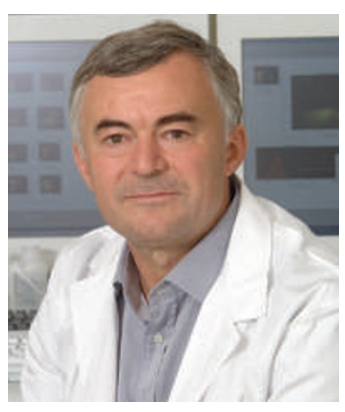

Rino Rappuoli opts for open interaction with the academic world.
Rome intervened, barring Marcucci from ending research at the site. Rappuoli then helped the company to find a buyer that wanted to exploit the research potential. Chiron, which was trying to develop AIDS vaccines at its headquarters in Emeryville, bought the lab in 1992 for an undisclosed price.

Chiron put Rappuoli in charge of its vaccine development, adding investment but interfering little with his personal style of open interaction with the academic world.

Today, the business has half-a-dozen vaccines in late-stage clinical trials, for diseases including meningitis and influenza, and many more in earlier stages of development.

And Novartis is widely expected to win European regulatory approval within the next few months for the world's first influenza vaccine that can be produced by cell culture, a procedure designed to replace the time consuming egg-based process. According to Novartis officials, the US Food and Drug Administration has indicated that it may not demand fresh US clinical trials if the product - OptaFlu - is approved in Europe.

"The potential of the vaccine pipeline is substantially larger than we anticipated," says Karl Heinz Koch, an analyst who watches Novartis for the Swiss bank Vontobel. "The cell-based flu vaccine alone could win over a significant part of the \$6-billion-a-year flu-jab market."

Before it acquired Chiron, of antisera and vaccines against diseases such as anthrax, typhus and cholera supported his research and the growth of the institute. By the 1950 s, the company was not only fulfilling all of Italy's vaccine needs, it was also supplying other countries including the United States.

But things later flagged. In 1983, the Sclavo Institute was acquired by the state-owned energy giant Eni. It was privatized in 1990 and then sold to the electronics firm Marcucci, which wanted to close the lab and build a hotel on the land.

Rappuoli - then Sclavo's director of research - rallied scientific friends around the world in support of the institute, and the government in
Novartis was not active in vaccines. But the company now aims to have doubled last year's sales by 2011, with the main earners being vaccines for influenza and for travel-related disease risks. It has pledged major investment in its vaccine programme, while absorbing Chiron's pharmaceutical division into its own.

According to Falkow, much of this vaccine success comes down to the research at the Siena laboratory - the source of most of Novartis' approved products as well as the half-dozen candidates in trials - and Rappuoli, who is now in charge of Novartis vaccine research worldwide.

About a fifth of the lab's scientists are not

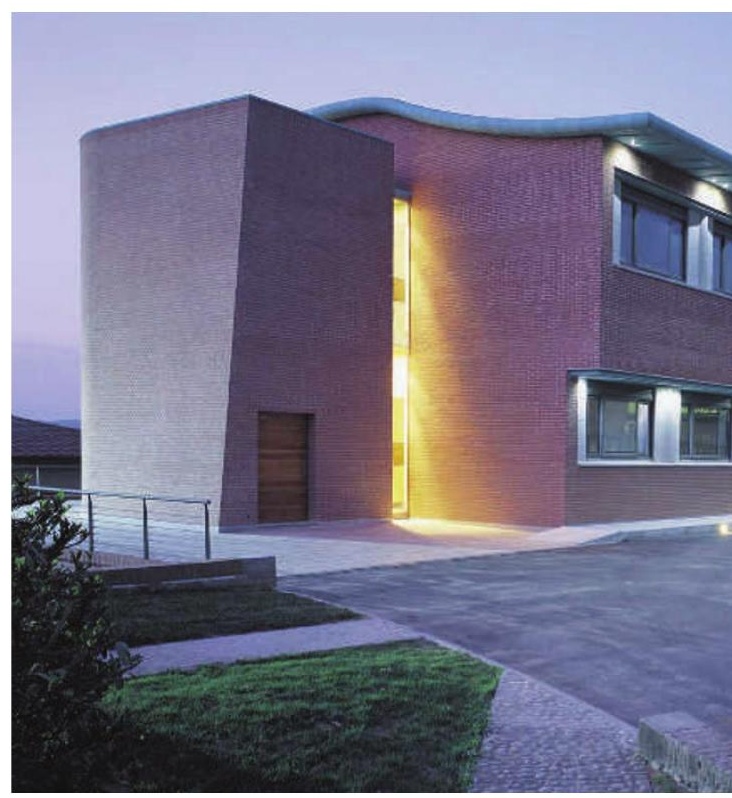

The Sclavo Institute has produced a treasure trove of vaccine candidates for Novartis.

Italian - quite a high proportion by Italy's standards. And although employed directly by the drug company, they are an integral part of the wider microbiology community, outsiders say. The staff speak openly about much of their research at meetings, publish in top-ranking journals and are acknowledged leaders in some areas of fundamental research. "Most of the Siena scientists are high level, publishing as much of their work as they can," says Philippe Glaser of the Pasteur Institute in Paris. "This situation is down to Rappuoli - he's an extremely good researcher and a good manager."

\section{Fresh targets}

The 150 or so scientists on the Siena site there are another 100 physicians and technicians working in clinical research - have made several important discoveries in the biology of infectious disease. They found, for example, how the bacterium Helicobacter pylori causes the specific damage to the stomach cells it infects that leads to ulcers or cancer.

They are also pioneering what Rappuoli calls 'reverse vaccinology', a technique that uses information from a microbe's genome to predict which of its proteins might be useful for vaccines.

One of the lab's most recent innovations was to use this method to identify structures called 'pili' in Streptococcus bacteria, which cause diseases such as meningitis. Pili are thin tubes of protein that protrude from the cell walls of the bacteria, helping them to stick to the mammalian cells they are going to infect. Scientists at Siena are now studying the feasibility of 


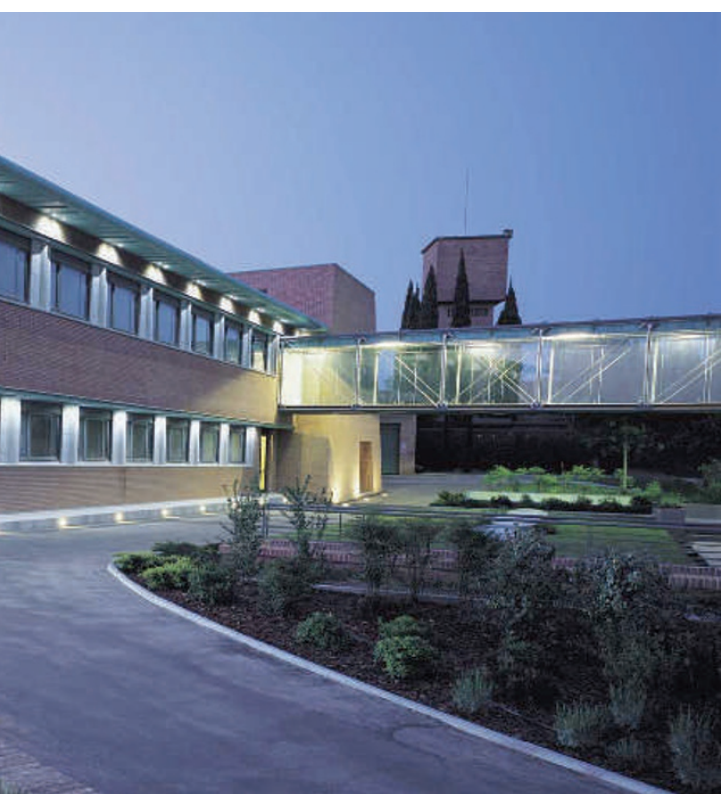

developing vaccines based on pili proteins.

Rappuoli says he welcomed the takeover by Novartis. Despite Chiron's innovative approach to product development and considerable commercial success, it never managed to bring a blockbuster drug to market, he points out. It just didn't have the cash to push all of its promising vaccine candidates through clinical trials. "Now Novartis is bringing them through fast,

"Most of the

Siena scientists are high level, publishing as much of their work as they can." - Philippe Glaser running trials in parallel," Rappuoli says. And researchers at the bench are pleased to have access to some of Novartis' powerful research resources in areas such as bioinformatics.

The future may be less bright for the 70 or so vaccine researchers who worked at Chiron's other main laboratory at Emeryville. Rappuoli is moving the unit to Boston, to be close to the drug researchers at the Novartis Institutes for Biomedical Research. "In the next 15 years," he says, "we'll pioneer a new field of combined therapy and immunotherapy." Combined vaccine and drug approaches could yield dividends in areas such as cancer or AIDS, he adds.

Novartis is already bankrolling another of Rappuoli's long-term visions - a separate research institute on the Siena campus, dedicated to developing vaccines for use in developing countries. Novartis has agreed to equip and staff the laboratory, which will look to foundations such as the local Monte dei Paschi di Siena and the Bill \& Melinda Gates Foundation to support its research projects.

\section{IN BRIEF}

FLU VACCINE The US Food and Drug Administration is set to approve the first vaccine for use in an avian flu pandemic. An advisory committee said the regulator should approve the vaccine, made by Sanofi-Pasteur, the vaccine arm of Paris-based SanofiAventis. The vaccine against the H5N1 strain of bird flu is only mildly effective, however, and will not be sold commercially. It is being bought by the US government for limited use in the early stages of a pandemic, before a vaccine better matched to the actual pandemic strain becomes available (see Nature 437, 619; 2005).

GREEN BUYOUT Plans for eight coal-fired power plants in Texas look likely to be scrapped as part of a proposed buyout of Dallas-based electricity generator TXU Energy. The US \$45-billion deal between TXU and investors led by Kohlberg Kravis Roberts \& Co. and Texas Pacific Group was endorsed by major environmental groups when it was announced on 26 February. The buyers say that as well as revising the plans for new power stations, they will commit to cut carbon dioxide emissions back to 1990 levels by 2020, and adopt strict environmental rules.

ABANDONED SPACE A six-year effort to launch a commercial space facility in Texas has been abandoned. Brazoria County, outside Houston, created the Gulf Coast Regional Spaceport Development Corporation in 2000 , hoping that it could find a private company to develop leased land into the world's first base dedicated to commercial space travel. But the county government said on 27 February that it was giving up on the idea.

\section{MARKET WATCH}

\section{CLEAN-ENERGY STOCKS}

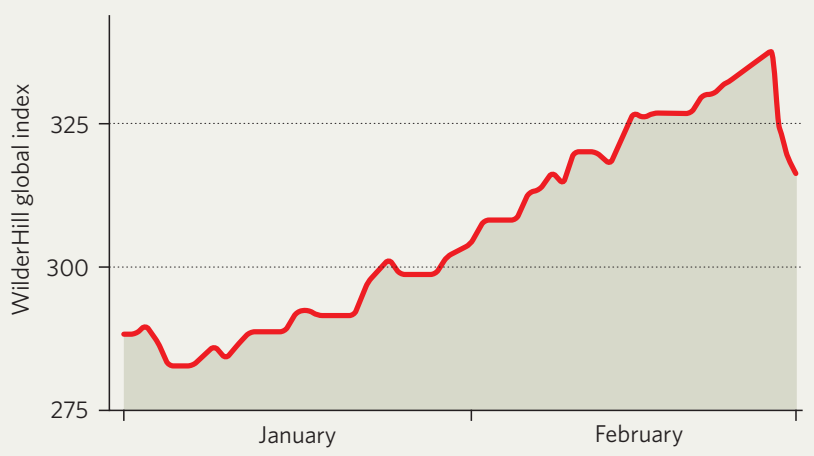

The stars have certainly been aligned in favour of clean-energy stocks early this year, as growing acceptance of the need to reduce greenhouse-gas emissions has bolstered the value of companies with interests in non-fossil-fuel sources of energy.

For 18 months, Nature has been tracking the value of a group of USbased energy companies. But this week we shift attention to an international selection of companies, which reflects the market for clean energy outside the United States. The WilderHill New Energy Global Innovation Index - NEX on the American Stock Exchange tracks the weighted values of about 60 of these companies around the world. At least until global markets dipped last week, the NEX index had been moving strongly upwards. The release of the fourth report from the Intergovernmental Panel on Climate Change on 2 February lent further impetus to a corporate trend in favour of clean energy, says Rob Wilder, founder of WilderShares, the California company that co-compiles the index with London-based New Energy Finance. "Even conservative people have been pushing their reservations aside and getting on board," he says. "They are saying: 'we don't love Al Gore, but

And Wilder notes that quiet and sector - such as a low-key 8 January announcement by US food giant Cargill that it is creating a subsidiary to build ethanol-processing plants - hint at good long-term prospects.

Even the global stock market correction on 27 February, which saw the Dow Jones fall by more than 400 points, confirmed the ebullience of the sector, says Michael Liebreich, head of New Energy Finance. "It was obviously hit by the correction," he says, "but less so than some main market indices." Colin Macilwain there's money to be made'." determined corporate moves into the 